\title{
Segregated Fields. Castilian and Morisco Peasants in Moclón (Málaga, Spain, 16th century)
}

Esteban López (Universitat Autònoma de Barcelona) [ORCID: 0000-0002-3137-6460]

Félix Retamero (Universitat Autònoma de Barcelona) [ORCID: 0000-0003-1586-340X] (Corresponding author. Research group Agrarian Archaeology of the Middle Ages [ARAEM: http://grupsderecerca.uab.cat/araem/]

Departament de Ciències de l'Antiguitat i l'Edat Mitjana. Facultat de Filosofia i Lletres Universitat Autònoma de Barcelona. 08193 Cerdanyola del Vallès (Barcelona- Spain) E-mail: felix.retamero@uab.cat)

\section{Running head:}

Segregated Fields. Castilian and Morisco Peasants in Moclón (Málaga - Spain)

\begin{abstract}
The aim of this paper is to analyse the distribution of the agricultural fields in the alqueria of Moclón (Málaga. Spain) after the Castilian conquest of 1485. Moclón was populated by seven morisco neighbours and five Castilian settlers during the 16th century, until the expulsion of the Moriscos in 1570. The study of written evidence and the archaeological survey have permitted us to locate the fields of both communities. Clearly, there were segregated areas of irrigated and dry fields. The internal distribution of the Moriscos' fields is also analysed. Finally, some explanations for this segregation are put forward.
\end{abstract}

Keywords: Moriscos $\cdot$ Agriculture $\cdot$ Expulsion $\cdot$ Castilian colonization

\author{
This is the pre-print version of the following article: \\ López, Esteban, y Félix Retamero. 2017. «Segregated Fields. Castilian and Morisco Peasants \\ in Moclón (Málaga, Spain, Sixteenth Century) ». International Journal of Historical \\ Archaeology, 21(3), 623-640. doi:10.1007/s10761-016-0390-1.
}

The final publication is available at link.springer.com: http://link.springer.com/article/10.1007/s10761-016-0390-1 


\section{Introduction}

The Iberian Peninsula experienced one of the longest processes of conquest and colonisation within the framework of the so-called 'expansion of Latin Christianity' in medieval Europe (Bartlett 1993; Baschet 2009). Between the twelfth and fifteenth centuries, the Christian societies of the Iberian Peninsula gained much experience of organising systematic pillaging expeditions and outright military conquests, as well as exterminating whole population groups. In addition, this process also led to the emergence of a new social order based, on the one hand, on the submission of the indigenous populations that stayed in their respective localities until the fifteenth- and sixteenth-century expulsions, and, on the other, on the settlement of Christian colonists. The new production strategies and the reorganisation of agricultural landscapes were key factors in the configuration of the post-conquest societies. The coexistence of the existing Andalusi population and the newly arrived Christian colonists was rife with tension; the two groups were not only separated by legal status and often by residence, but they also followed different organisational criteria and adopted different production strategies.

This article combines an analysis of the written record and toponymy, as well as ethnographic and archaeological survey in order to examine the coexistence of Muslims and Christian colonists in Moclón, a small alquería in the Genal Valley (Malaga), in the western regions of the Kingdom of Granada, between the time of the Castilian conquest of 1485 and the expulsion of the population of Andalusi descent in 1570. Owing to the scarcity of this sort of study, no general conclusions can yet be reached, but the example of Moclón suggests that the location of the fields owned by Moriscos - people of Andalusi ancestry - and by Christians was largely determined by the adoption of different agricultural regimes.

Despite the capture and deportation of a portion of the indigenous population, and also the measures adopted in order to quash the revolts that broke out against the Christian occupation, in the early sixteenth century, Muslims still made up a significant proportion of the population in some densely populated areas of former al-Andalus, such as the Ebro Valley (Catlos 2004; Ferrer 2002; Laliena 2005), the region of Valencia (Baydal and Esquilache 2014; Torró 2006) and the Kingdom of Granada (Galán 1991; Galán and Peinado 1997; Ladero 1969, 1988). Before their forced conversion to Christianity between 1500 and 1526, these groups came to be known as Mudéjares (Barrios 2008; Galán 1991; López de Coca 1994). Other regions, for example the Balearic Islands, did not witness this period of coexistence, as the conquest, which took place in the thirteenth century, was immediately followed by the extensive capturing and deportation of the conquered population (Ferrer 2015, pp. 71-7; Jené 1985-86; Mas 2005; Soto 1994). The final suppression of the last remaining pockets of Moriscos, as they were known after their conversion, was undertaken 
between the late sixteenth and early seventeenth centuries. In the earliest regions to be conquered, namely the Ebro Valley (conquered in the twelfth century) and the region of Valencia (in the thirteenth), the Muslim or 'converted' groups coexisted with Christians for over three centuries, up to the time of their expulsion in 1609 (Torró 2006; Viciano 2012). In the Kingdom of Granada, which was reorganised by the Castilians after its conquest in 1492, coexistence barely lasted one full century (Domínguez and Vincent 1978; Galán 2010; Vincent 2000).

The position of political subservience inflicted on the conquered populations generally worsened over time (Guichard 1992, p. 195), but the situation varied greatly according to region. For instance, the Castilian Mudéjares lost that condition and were forced to convert after the 1499 revolt in Granada. As a result of the uprising, the Mudéjares from Granada were forced to convert in 1500, and in 1506 the policy was extended to the rest of the territories of the Crown of Castile (Domínguez and Vincent 1978; Barrios 2008). Naturally, there were differences in wealth and status within the subject Islamic groups, and some families and individuals, especially those who made up the local elites, found it easy to fit into the post-conquest political and legal status (Galán 1987).

However, in general Moriscos were politically and physically segregated, collectively subjected to what was in practice a regime of servitude. The separation, the 'segregated reproduction', of Christian and Muslim communities was a necessary condition for the subordinate position of the latter (Torró 2000, p. 1007; Viciano 2012), and this materialised in multiple ways: Muslims had to pay higher taxes, they had to render personal services, their movements were restricted, they were restricted by rules on inheritance; also, they were forbidden (often unsuccessfully) from speaking Arabic, marrying cristianos viejos ("Old Christians", as oposed to the "New Christians" or Moriscos), wearing certain garments and indulging in certain celebrations, etc. (Torró 2009a; Ferrer 2002; Galán 2010, pp. 95-104; Barrios 2008). In Valencia, for example, their taxes were more onerous than those paid by their Christian neighbours and included corvées, and their movements were restricted (Viciano 2012; Torró 2009a; Vincent 2015; Galán 2007, 2010).

Needless to say, the coexistence of these different social groups raises issues concerning the continuity of pre-conquest Andalusi social practices and the pace and scope of the changes introduced with the arrival of the Christians (Catlos 2004). It seems, at any rate, clear that the crystallisation of the new colonial society resulted in new practices that incorporated those of the vanquished society only partially, and in a deformed shape. For example, Josep Torró (2009a) has demonstrated that some taxes in Christian Valencia were very different from those in force in Muslim Valencia, despite having the same names. Similarly, the frequent description of the operation of water-distribution systems 'as it was done in the time of the Moors' suggests that irrigation systems were 'ultra-stable' (Glick 1989; 1996), but this conceals the very substantial modifications undergone by traditional water-allocation systems in the context of a new economic strategy and social hierarchy (Guinot 2008; Retamero 2014).

This does not mean that Andalusi groups did not preserve some of their earlier social practices. In fact, as previously noted, differences, even after forced conversion, was a key condition of segregation, which formed, in turn, the basis for the political submission of the indigenous groups (Torró 2009a). Conversely, segregation enabled Mudéjares and Moriscos 
to retain traditional solidarity ties, which helped them to bear the high taxation. Similarly, traditional domestic arrangements and social practices survived better in those communities that stayed compact and separated from the Christians (Torró 2009b).

Historiography has paid considerable attention to different aspects of this segregation. One of the clearest expressions of it was the physical separation of areas of residence. For example, after the twelfth-century conquest, in many towns in Aragón and the Ebro Valley the Mudéjar population was concentrated in separated districts (morerias) (Catlos 2004, p. 94; Gerrard 1999; Torró, 1995; Virgili 2001, pp. 110-112). Something similar took place at a later date in Valencia (Torró 1999) and West Andalusia (Ladero 1981; González 1988), and finally also in Granada after 1492 (Galán 2000, 2007; Peinado 2012). In some places, such as the village of Tolox (Malaga), there were even different cemeteries, for the Morisco and the Castilian inhabitants (López 2013, p. 32). However, despite the popularity of the general issue among historians, the distribution of agricultural land in areas where Muslims and Christians coexisted is a comparatively understudied topic (Barrios 1993; Esquilache 2009; Colás 1993; Laliena 2008).

In rural areas of the Kingdom of Granada from whence the indigenous population was not systematic expelled, the proportion of Christians and Muslims varied greatly. The volatility of the numbers involved in military campaigns and the difficulties of colonising the conquered regions, in addition to the population shifts caused by fleeing and displaced Muslim groups, contributed to this uneven distribution (Ladero 1993; Galán and Peinado 1997).

In the hills of Ronda (Malaga), on the western border of the Kingdom of Granada, there were certain places in which no Muslims could be found shortly after the conquest, for instance the city of Ronda after 1485, or the hamlet of Pujerra in the early sixteenth century (Acién 1979; Malpica 2014, pp. 501-520); in other places, however, few or no Christians lived before the 1571 expulsion, for example Igualeja (Rodríguez 2005); finally, in other places the number of Christians and Muslims was almost equal, for instance in the hamlet of Moclón, in the Genal Valley, district of Havaral, Ronda (Acién 1979; Becerra and Siles 2013). This article examines the example of this small village, focusing on the agricultural regimes and the location and size of agricultural lands owned by the last Moriscos and the cristiano viejo families stablished there after the Castilian conquest of 1485. Using information from written, archaeological, toponymic and ethnographic sources, we can outline the agricultural arrangements adopted by the two coexisting peasant groups over a period of seventy years.

\section{Texts, archaeological survey and ethnographical record}

Although the bibliography on agricultural landscapes in the Kingdom of Granada is considerable (e.g. Malpica 1995, 1997, 1999, 2006, 2014; Trillo 1994, 2005, 2006; Martínez 2006), few studies analyse in sufficient detail the physical distribution and size of agricultural fields in areas where Moriscos and Castilians coexisted; such an analysis must involve the careful delimitation of field boundaries and associated structures (walls, earth banks, acequias, mills, etc.), as well as the paths that linked the field systems with the residence areas. 
The combined use of textual information and fieldwork has revealed the distribution of the land cultivated by each group in the seven decades that preceded the expulsion of the former Andalusi inhabitants of Moclón. Without this information, it would be difficult to broach issues that concern the social choices and the constraints that lay behind this spatial distribution. Archaeological and ethnographic surveys took place in the summers of 2012, 2013 and 2015. Aerial photographs were used to identify the agricultural spaces mentioned in the written record. Some of the pagos (agricultural areas) mentioned in sixteenth-century documents were identified through the data collected via ethnographic survey. Old place names, which are still known and used by locals, are often not present on modern maps or they are wrongly situated.

The identification and description of these fields involved the delimitation of their boundaries, the location of the acequias, in the case of irrigated fields, and paths, and the estimation of the size of cultivated and non-cultivated areas. This study adopts the methodology of hydraulic archaeology developed in order to analyse Andalusi irrigation agriculture in the Iberian Peninsula and the Balearic Islands (Barceló et al. 1996; Kirchner 2009; Kirchner and Navarro 1994).

Concerning texts, this analysis makes use of archive documents issued by the governing bodies of the Kingdom of Granada after the expulsion of the Moriscos, including the Libro de Repartimiento, redacted in 1572 and recently transcribed and edited by M. Becerra and F. Siles (2013); the visitas reports, inspections carried out by royal officials to monitor the new colonists; the archives pertaining to the installation of a tinplate factory near Moclón in the eighteenth century (Sierra and Sierra 2013), which include different textual and graphic references to the Genal Valley; and the cadastre commissioned by the Marquis of Ensenada in 1752, which has allowed us to compare the areas under cultivation in 1572 with those that were being used for agricultural purposes two centuries later.

\section{The Castilian Conquest and the Colonization of the Genal Valley}

The conquest of Ronda in May 1485 and the surrender of Marbella the following June was a heavy blow for the Nasrid sultanate of Granada. The war of conquest, initiated in 1482, began to bear fruit in the spring of 1485, when the Catholic Monarchs imposed their rule on the westernmost region of the kingdom. Ronda and Marbella were the capitals of extensive districts, and thus after their surrender to Ferdinand the Catholic a large number of smaller settlements followed suit and capitulated (Ladero 1993, p. 66). The conditions agreed for the surrender stipulated that the new subjects would be allowed to keep their property, practise Islam and obey their own laws; in exchange, the taxes that they had hitherto paid the Nasrid Crown would thenceforth be paid to the Castilian monarch (Acién 1979, p. 317). These pacts were soon broken, and the excessive taxation imposed by the Crown as well as the forced conversions prompted by Cardinal Cisneros triggered a rebellion which broke out in the city of Granada towards the end of 1499 (Barrios 2008, p. 74) and reached the hills of Ronda in the closing months of 1500 (Martínez and Castillo 2007).

The bloodiest clashes between the Mudéjares and the Castilian militias took place in the hills of Ronda, for instance the battle of Rota del Calaluz (Martínez and Castillo 2007), in which the Castilians suffered a heavy defeat. King Ferdinand's troops were finally victorious 
in 1502 and the Mudéjares were left no alternative but to flee to Barbary (North Africa) or accept baptism. Many residents in the Genal Valley chose exile, and the void left by their absence had to be filled with Castilian colonists, as established in an order dated to 1501 (Acién 1979, p. 364). The colonists were encouraged to take the new land with tax incentives, while the Moriscos (who were now officially Christian) were forced to pay fresh tributes. This form of discrimination was one of the main causes of resentment between both communities in the years that followed the forced conversions (Galán 2000; 2010).

Conquest, flight, rebellion, expulsion and the arrival of colonists had a notable impact on the demographic configuration of the Kingdom of Granada at the turn of the sixteenth century. In some villages, such as Júzcar, approximately $80 \%$ of the former inhabitants decided to stay. Other places, such as Moclón, were left virtually depopulated for several years (Acién 1979, p. 364). The opening years of the sixteenth century were characterised by instability, and the former inhabitants were often forced to change their place of residence to make room for newly arrived colonists. For example, Pujerra, near Moclón, retained a small Morisco community for several years, but by the mid-sixteenth century none remained (Becerra and Parra 2013, p. 218).

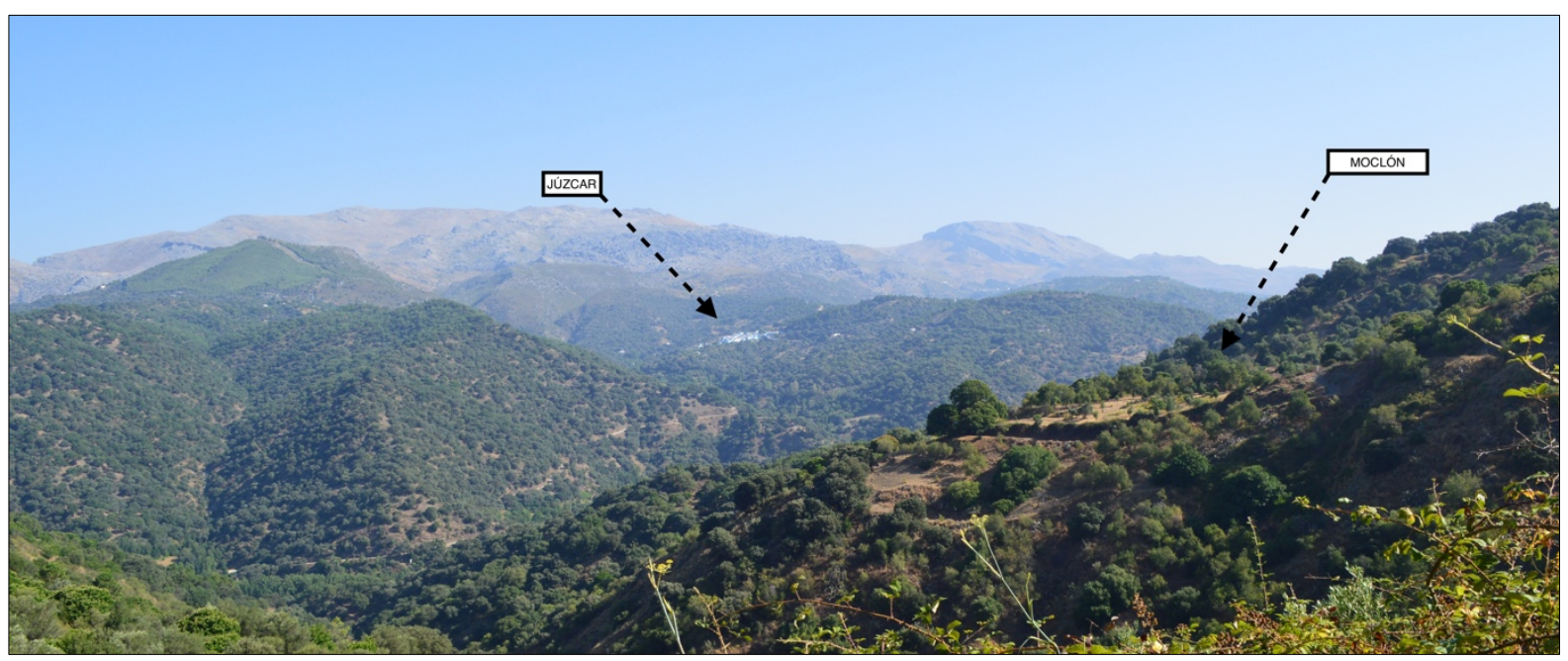

Photo 1. View of the Havaral district (Genal Valley. Málaga)

Moclón is now an abandoned settlement in the municipality of Júzcar, south of Ronda (Fig. 1; Photo 1). The ruins of the houses inhabited by the last dwellers, who left in the 1970s, are still visible. Despite the obvious changes, the modern houses stand on the same land as that on which the dozen or so houses documented for the sixteenth century were once built (Becerra and Siles 2013, p. 63). The hamlet is located on a slope above the Genal River, which is the main axis of the region. Despite its small size and temporary periods of abandonment, Moclón was an administrative and tithe-collection district until the municipal reform of the nineteenth century. In the 1752 cadastre, the territory of Moclón comprised 1,000 fanegas (around 612 has), the distribution of which roughly coincided with that recorded in the sixteenth-century Repartimiento.

According to a tax inventory issued in 1489 , five years after the conquest, the inhabitants of Moclón paid tithes of bread (wheat and barley), fruit (raisins) and livestock, as well as pares, 
a tax on the use of yokes (Acién 1979, p. 100). Another document records thirty male residents over sixteen in 1492 and thirty-five in 1497 (Acién 1979, p. 60). The first Christian colonists arrived after the revolt had been defeated in 1502 (Acién 1979, p. 369). The limited available evidence for the opening decades of the sixteenth century makes it impossible to ascertain exactly how much time elapsed between the end of the Mudéjar revolt and the arrival of the first cristianos viejos colonists in Moclón, but we do know that some had already arrived as early as 1506. It is also hard to tell whether the proportion of Muslims and Christians changed over time or remained stable after the arrival of the first colonists. Moclón does not feature again in the written record until the 1560s. The documents from this period indicate that the distribution of the population did not change substantially between 1561 and 1570. Before the Morisco rebellion of 1568 Moclón had a total of eleven households, five of which were cristianos viejos and six Moriscos (Relación del encabezamiento del alcabala de Moclón 1561). The report of the visita undertaken in 1571 and the inventories of the property left by the dead or the expelled Moriscos yield similar figures: seven Morisco and five Castilian households (Visita de inspección a Moclón 1571; Becerra and Siles 2013, p. 63). In 1572, the former Morisco houses were handed over to the new colonists. The description provided in the 1572 repartimiento indicates that the Morisco and the cristianos viejos houses were intermingled.

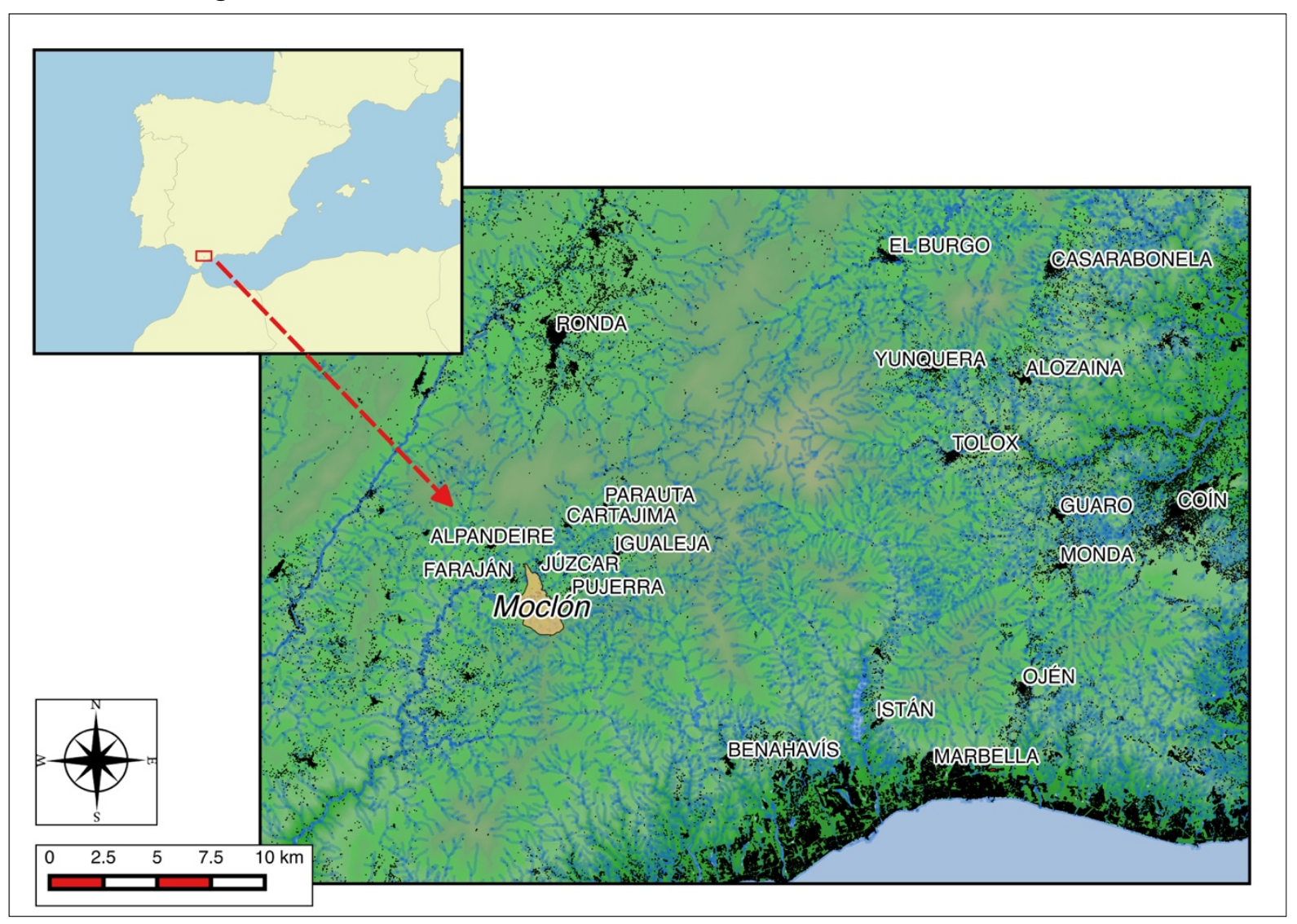

Figure 1. Location of Moclón (Málaga. Southern Spain)

The fact that the same family names feature in the record for 1561 and 1570 speaks of stability, but this stands in sharp contrast with what occurred after the expulsion. Although most of the ealier Castilian families stayed in the hamlet until the early seventeenth century, 
the expulsion led to a period of volatility that affected, firstly, the former Morisco properties: e.g. illegal sales and occupations (Becerra and Siles 2013, p. 186-200). This situation also affected those Christians who had coexisted with the Moriscos: after the opening years of the seventeenth century, the family and property structure of Moclón had changed beyond recognition.

\section{Castilians and Moriscos. Size and Distribution of the Fields}

An analysis of the record of the repartimiento of 1572 (Becerra and Siles 2013) and of the visitas carried out after the expulsion provides us with much information concerning the size and distribution of agricultural fields owned by the Moriscos, and also the criteria followed for the allocation of this land among the new Castilian settlers. What the inventories do not describe is the land owned by the earlier Christian settlers. In any case, the description of the boundaries of the Morisco property recorded in the Libro de repartimiento and the eventual identification on the ground of these plots of land have been used to identify which lands were Christian-owned before the expulsion. A considerable proportion of the toponyms used in sixteenth-century documents has survived, and it is therefore possible to link plots of land and their respective areas (pagos), regardless of their exploitation regime (irrigation or dryland agriculture).

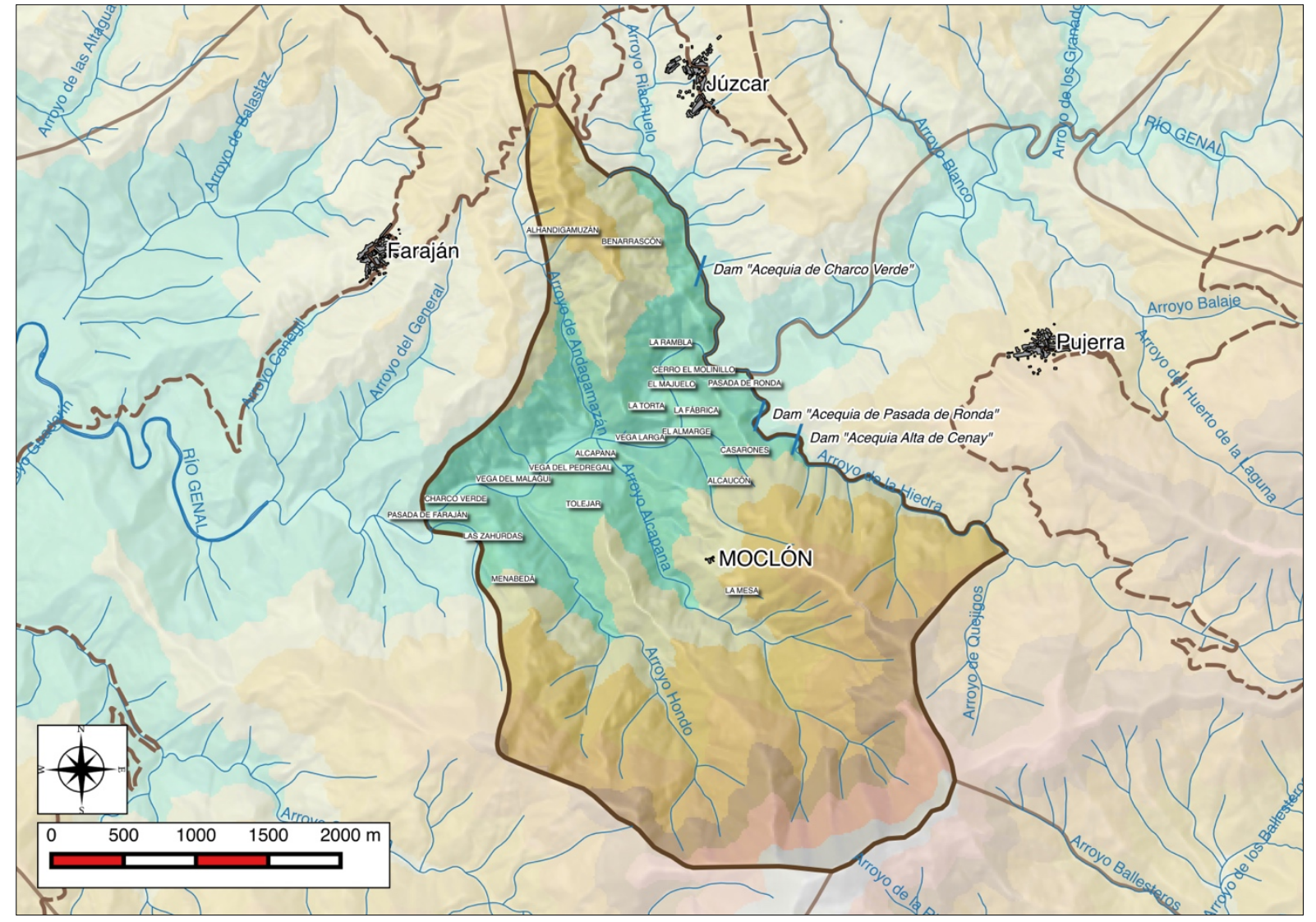

Figure 2. District of Moclón 
The dezmería (tithe-district) of Moclón was a mountainous area, 612 ha in size, which was mostly covered by holm oaks and cork oaks (Fig. 2). The agricultural fields barely amounted to one-tenth of the whole area. According to the report of a visita undertaken immediately after the expulsion of the Moriscos in 1571 the district of Moclón dedicated 30.6 ha to dryland agriculture, 11 ha to irrigation agriculture and 17.3 ha to vines. Fruit trees existed, but were scattered all over the district, both inside and outside cultivated fields, and were not in compact groves. Some Moriscos who lived outside the district possessed land in the dezmería of Moclón.

One-third of the dry fields (10 ha) were owned by Moriscos; of these, 3.6 ha were situated near the hamlet, in small plots. The remaining non-irrigated fields were farther away from the hamlet. On the other hand, some of the Moriscos also possessed lands outside the district, specifically in the district of Ronda (Visita de inspección a Moclón 1571; Becerra and Siles 2013, pp. 74-82). Hernando Retal was the wealthiest Morisco, with a total of fourteen plots ( 2.5 ha in total). At the time of the expulsion, the five Christian families owned 20.5 ha of dry fields, distributed in blocks which were located beyond the plots owned by Moriscos, near the houses, and at the far end of the district.

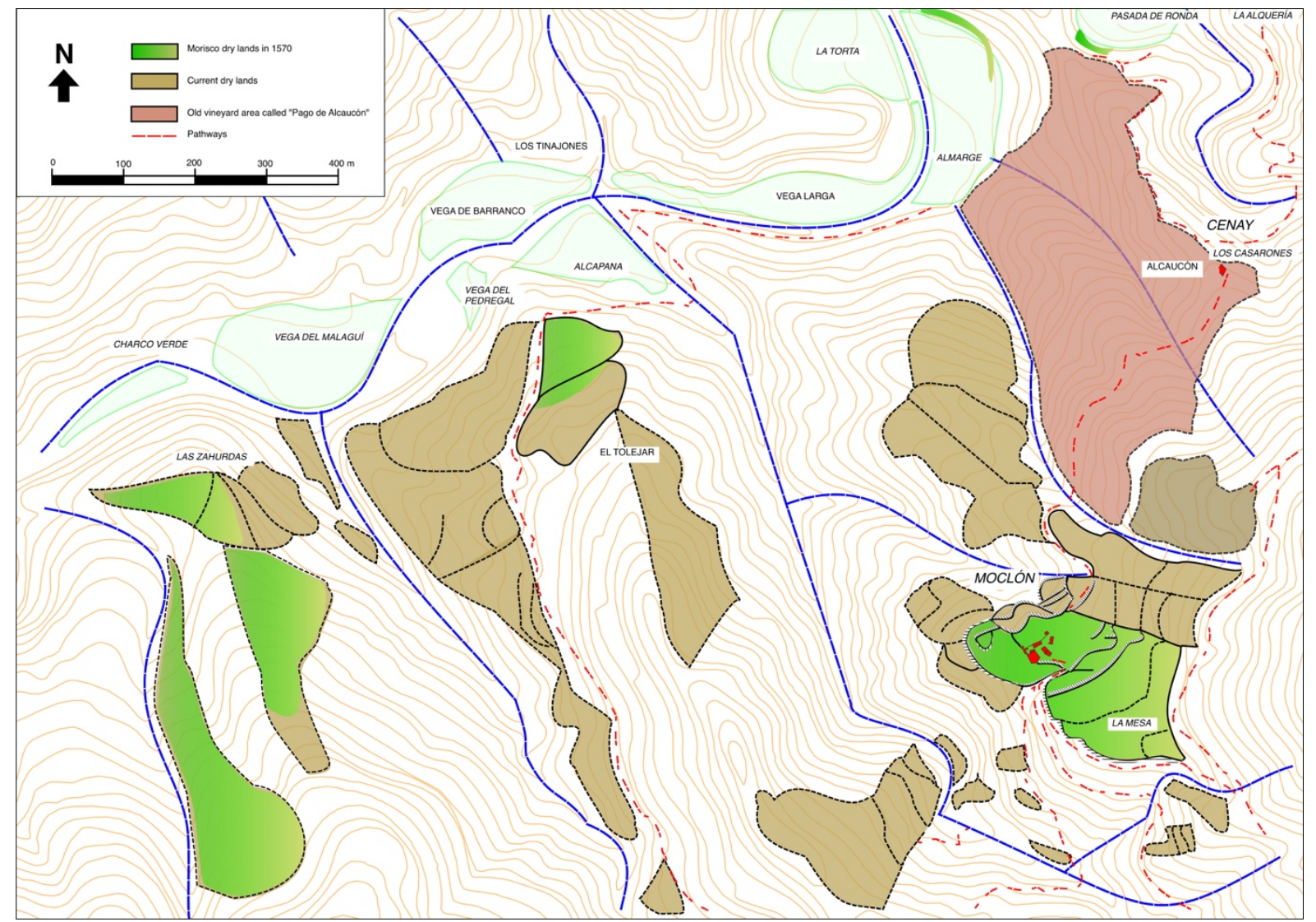

Figure 3. Distribution of the dry fields of Moclón

The irrigated fields were located near the river, either at the valley bottom or on the terraces built into the slopes of both river banks. In total, at the time of the expulsion, the aggregate size of the irrigated plots was 11 ha, 3.6 ha of which belonged to Moriscos (Visita de inspección a Moclón 1571; Becerra and Siles 2013, p. 98). As was also the case with the dry 
fields, Hernando Retal was the wealthiest Morisco in 1571 as far as irrigated land was concerned: he possessed sixteen irrigated plots, with an aggregate size of 0.76 ha.

We have information on the location and size of the property of four of the seven Morisco heads of household. It is unclear whether the property of the other three is not recorded because they did not have any or because the clerk in charge of noting down the names of the former landowners of the lands to be distributed was inconsistent in his task. The names of the Morisco owners of up to twenty-two of the irrigated plots recorded in the repartimiento were not included on the register (Becerra and Siles 2013, pp. 203-206).

Although there were clear differences in wealth among the Moriscos of Moclón, their properties were always fragmented in multiple small plots that were scattered both near the houses and farther away. As previously noted, the 1572 repartimiento registered Hernando Retal as the owner of 2.5 ha of dry fields distributed in fourteen different plots, and 0.23 ha of irrigated fields distributed in no less than ten plots (Becerra and Siles 2013, pp. 93-101). This tendency for fragmentation and the dispersion of property among Mudéjares and Moriscos has been attested elsewhere in the Kingdom of Granada (Galán 1991, pp. 179-186; Trillo 2004, 2005, 2006; Martínez-Enamorado 2006), and also in areas that were conquered in the twelfth and thirteenth centuries, such as the Ebro Valley (Ortega 2000) and Valencia (Furió and Garcia-Oliver 1985-86; Torró 2006).

It is, however, worth noting that the plots owned by Moriscos of Moclón tended to be concentrated in specific areas (pagos). Their possessions generally formed compact clusters instead of being evenly distributed throughout the district. These concentrations are clearly visible in the case of the small non-irrigated plots (often called hazuelas) located besides the houses. Figure 3 illustrates the location of these fields, according to the information recorded in the 1572 repartimiento. As can be appreciated, up until the time of the expulsion the Moriscos possessed a compact block, 3.6 ha in size, near the hamlet. Its proximity to the houses and its small size made it easier to tend and also facilitated the immediate use of domestic waste and the dung produced by the livestock kept near the houses. The Christians did not possess any land within this block. In addition, although Morisco fields systematically bordered other Morisco fields, the properties of any given individual were scattered, instead of forming solid clusters. For instance, Hernando Retal owned 7 plots in this area, with an aggregate size of 1.2 ha, but none of these plots bordered one another.

Although the outline of this block of land near the houses can be confidently established through fieldwork and aerial photography (photographs taken in 1956 and 1977), it is not possible to identify the limits of each individual Morisco possession. According to the descriptions conveyed by the Libro de repartimiento (Becerra and Siles, 2013), none of these plots was larger than $3000 \mathrm{~m}^{2}$ and most were under $1000 \mathrm{~m}^{2}$. In general, current plots are larger than the individual Morisco possessions registered in 1572. This lack of correspondence may be due to the fact that Morisco properties did not overlap with the boundaries of the plots (usually demarcated by earth banks or dry-stone walls) or the fact that later rearrangements have erased the old boundaries.

Figure 3 also illustrates that the remaining 6.5 ha of dry fields in the hands of Moriscos were located at a distance of approximately $1.5 \mathrm{~km}$ from the hamlet, in the pagos of Tolejar, Menabedá and Zahúrdas. In these areas the plots were a lot larger than those situated 
near the houses. The plots of land allocated to the new settlers after the expulsion were over 1 ha in size, and formed considerably larger blocks.

The overall size of the fields located near the houses and those in the more distant pagos corresponds with the 16.6 fanegas (10.1 ha) of dry fields which, according to the visita carried out by the commissary Arévalo de Zuazo (Visita de inspección a Moclón 1571), were the property of Moriscos. This land, according to this report, amounted to one-third of the total dry fields. The other two-thirds ( 33.3 fanegas; 20.5 ha) were the property of Castilians. Obviously, the Christian-owned land was not subject to the distribution undertaken after the 1572 repartimiento, and is, therefore, not described in the inventory.

In any case, the Christian-owned agricultural areas can be established with some precision. Based on the analysis of the aerial photographs, the mapping of the slopes, and field observation of the current land-plot distribution, we have calculated that the areas sown with cereal in the mid-twentieth century amounted to a maximum of 39 ha, that is, 8.5 ha more than what Zuazo recorded in 1571 . The delimitation of the areas in which cereal could be sown, and that of the fields formerly owned by the Moriscos, has led us to conclude with confidence that the Christians of Moclón owned land situated mostly in the area known in 1572 as the hazas (arable plots) of Moclón, between the pago of Alcaucón (occupied by vineyards) and the small plots near the hamlet (all of which belonged to Moriscos), and also in the pagos of Tolejar, Zahúrdas and Menabedá, where, as previously mentioned, the Moriscos had their larger cereal fields (Fig. 3). The references to these fields in the repartimiento can be used to estimate the size of the Christian-owned fields in these areas at the time of the expulsion (Becerra and Siles 2013, pp. 266 and 269).

Although there were vineyards scattered throughout the district of Moclón, the main clusters were in the pagos of Alhandigamuzán and Benarrascón, which was on the far side of the river, and Alcaucón, which was closer to the hamlet. Most of the former belonged to Moriscos who lived in the nearby villages of Faraján and Júzcar (Fig. 2) (Libro de repartimiento de Júzcar, 1572, fol. 15v). The vineyards in the pago of Alcaucón were owned by residents of Moclón, especially (but not exclusively) Moriscos. Overall, the area dedicated to vineyards in the pagos of Alhandigamuzán, Benarrascón and Alcaucón was approximately 18 ha in size. This is in addition to the Christian-owned vineyards, the size of which is unknown. It seems that, unlike the arable fields and, as we shall see presently, irrigation fields, the vineyards owned by cristianos viejos and Moriscos were mixed. 


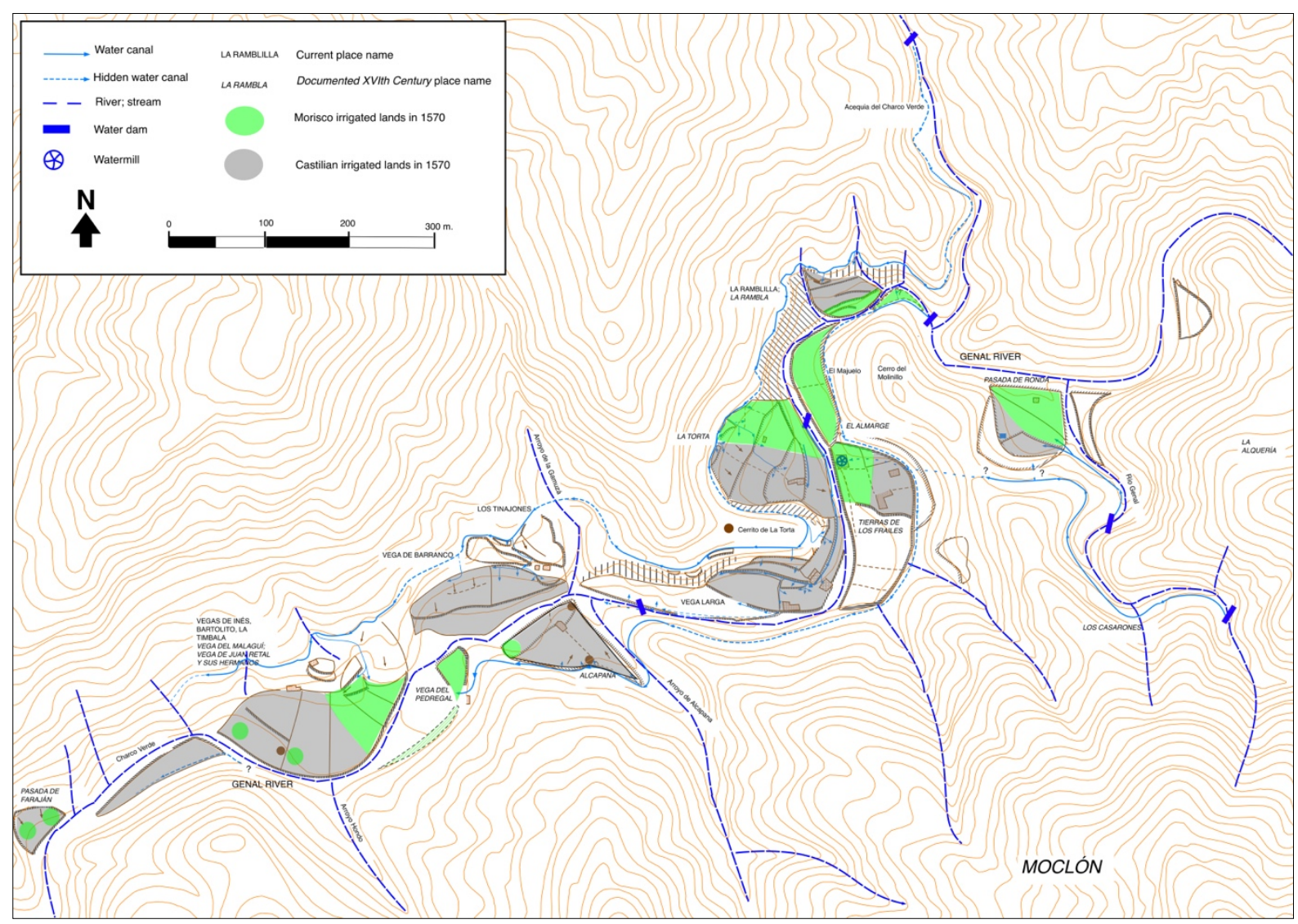

Figure 4. Distribution of the irrigated fields of Moclón

According to Arévalo de Zuazo, the Moriscos of Moclón owned 10 of the 30 fanegas of irrigation land in the district. The total size of these plots was $3.67 \mathrm{ha}$; the Christians owned twice as much (7.34 ha) at the time of the expulsion. The description of the boundaries contained in the Libro de repartimiento is not exhaustive, but is eloquent enough to help us locate the Morisco-owned irrigated fields. As illustrated in Figure 4, these fields (called bancales or bancalejos if they were terraced and vegas if they were not) were situated in the pagos of La Rambla and La Torta, on the one hand, and Pasada de Ronda and Almarge on the other. Downriver, the Moriscos fully owned Vega del Pedregal and part of Vega del Malaguí and Pasada de Faraján. In Alcapana there was a single bancal which belonged to a Morisco.

The plots in La Rambla (0.8 ha) and La Torta (1.8 ha) were the closest to the watercatchment point in the acequia (Photo 2). According to the repartimiento, the aforementioned Morisco Hernando Retal owned seven bancales in this area. There are no references to other bancales in this area, either owned by Moriscos or Castilians. In La Torta, for its part, the records mention several owners, most of whom were cristianos viejos. The description of the boundaries indicate that the Morisco plots formed a compact group at the southern end of the pago, spreading over the slope between the acequia and the river. 


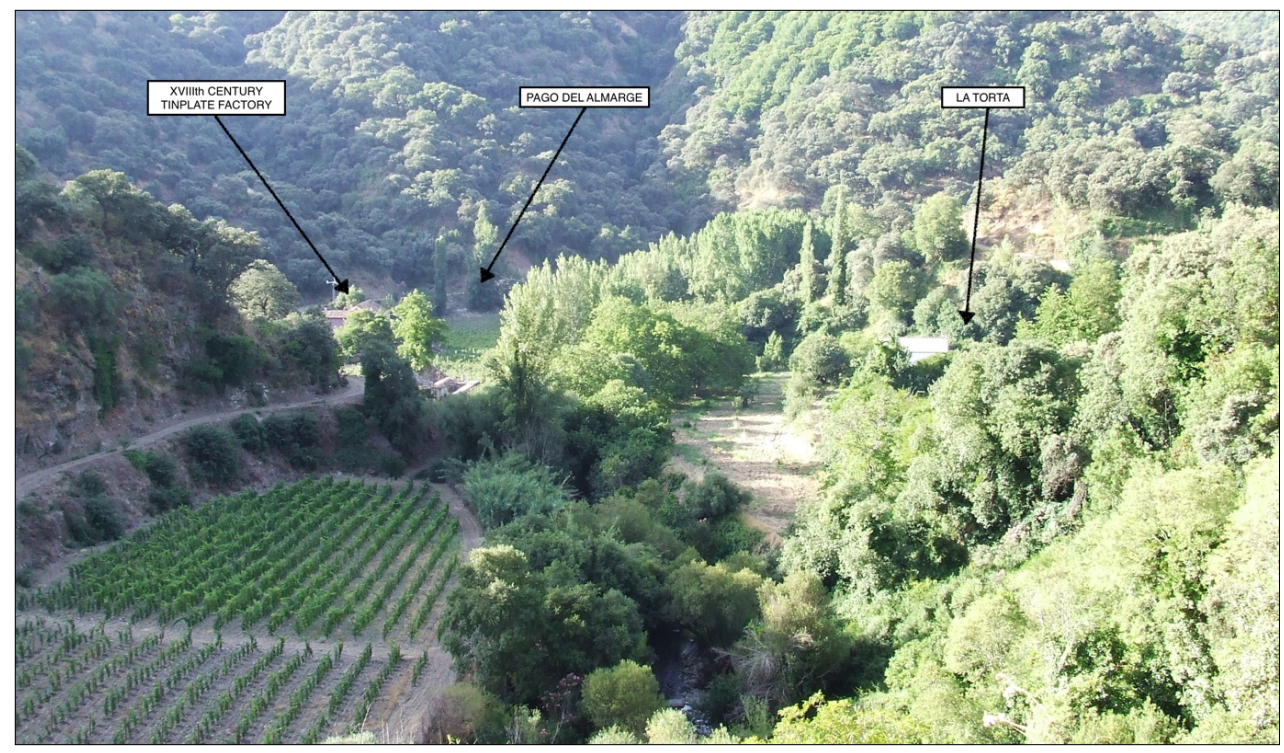

Photo 2. View of some irrigated pagos of Moclón

Pasada de Ronda was an irrigation system that enjoyed its own water-catchment area. It comprised seven Morisco terraces located towards the bottom of the valley, near the river. The upper terraces belonged to the cristiano viejo Corrales (Fig. 4). Further down, a branch of the river brought water to the pago of Almarge, where the only watermill of Moclón once stood. The watermill was pulled down in 1726 for the construction of a tinplate factory which reused the mill's channel (Sierra and Sierra, 2013). The maps produced in the eighteenth century by the factory architects reveal that the vega of Almarge, also known as del Molino, was at that time much smaller $(0.9 \mathrm{ha})$ than it is today $(1.75 \mathrm{ha})$. The whole area was covered in Morisco-owned bancales which, with the construction of the factory, or perhaps earlier, were flattened out. The 0.9 ha indicated by the factory map and the identification on the ground of old property boundaries correlates with the amount of land allocated to the new settlers after the expulsion. The Vega Larga, in which, according to the record, there were no Morisco-owned plots, was also enlarged at some point after the expulsion. Also free from Morisco-owned fields was the Vega de Barranco. None of these vegas are mentioned in the Libro de repartimiento, so it can be confidently assumed that they belonged to Castilians.

Figure 4 illustrates the distribution of the different plots, based on the incomplete information supplied by the Libro de Repartimiento, and the identification of field boundaries, which was achieved by a combination of survey and the analysis of aerial photographs. In total, according to these estimates, the Morisco-owned irrigated areas occupied 3.9 ha, a little over Arévalo de Zuazo's estimates in 1571 (3.6 ha). On the other hand, Castilian-owned irrigation fields, on which the Libro de Repartimiento provides next to no information, total 11 ha - the same figure estimated in the 1571 visita. The distribution suggested by Figure 4, therefore, almost coincides with the proportions recorded by Zuazo in 1571, and indicates that, in addition to having more irrigation land than the seven Moriscos expelled in 1572, the five cristianos viejos occupied the lower sectors of irrigation areas. In contrast, the Moriscos, with the exception of the five bancales which were situated in the vegas located at the tail end of the irrigation system, generally owned the highest plots. These terraced plots completely filled the pagos of La Rambla, Almarge and Vega del Molino, and 
took up just under a third of La Torta. Like the dry fields near the hamlet, the small irrigation plots owned by the Moriscos in these areas formed a compact block, even if the different properties owned by each individual were separated from one another.

\section{Conclusions}

The expulsion of the Moriscos of Moclón and the distribution of their property among a fresh batch of Christian colonists led to the dissolution of an agricultural order in which two peasant groups had managed to coexist for approximately seventy years. The agricultural structure that emerged from the expulsion of the Moriscos and the distribution of their land was characterised by the volatility of the new settlers, some of whom had played an active role in the military operations launched to put an end to the Morisco revolt.

The analysis of the report issued by Zuazo in 1571 and the Libro de repartimiento published in 1572 led to the reconstruction of the size and distribution of the agricultural lands, both Morisco- and Castilian-owned, at the time of the expulsion. The houses where they all lived formed a small hamlet which comprised a total of twelve households. Nothing is known about the everyday coexistence of these communities in such a small hamlet between the settlement of new colonists in the early sixteenth century and the expulsion of the Moriscos in 1570. The distribution of fields, however, seems to indicate different trends that, without doubt, played a relevant role in the coexistence of Moriscos and cristianos viejos.

In general, the property of individual Moriscos did not form continuous blocks of land. Hernando Retal, who owned more land than any other Morisco in the hamlet, had to his name 2.5 ha of dry fields divided into fourteen plots, and 0.76 ha of irrigation land divided into seventeen bancales, seven of which were located in La Rambla. With the exception of this pago and the vineyards, the Morisco properties were generally interspersed with one another but not with the Castilians'. The Morisco-owned dry fields were located in a compact block near the hamlet; this is a common practice in labour-intensive agricultural regimes, in which the proximity of human and animal dwellings and the constant transit of people facilitated the deposition of organic matter (Jones 2005; Van der Veen 2005). In fact, these practices are more akin to the intensive cultivation regimes that characterise irrigation agriculture than with dryland agricultural strategies, in which the cadence of tasks and harvests is slower.

The fields that were farther away from the hamlet, which were also the largest, were located in the pagos of Tolejar, Zahúrdas and Menabedá. These fields were used for dryland agriculture, but it is likely that the labour regime and fertilisation practices, and even crop rotation and harvest cadence, varied depending on the size of the plots and their distance from the hamlet. It appears that the officials in charge of the distribution of the Morisco land after their expulsion thought that these qualifications were irrelevant, and merely distinguished between dryland areas (secanos) and irrigated fields (regadios).

As with the group of small plots (hazuelas) near the houses, collectively the Moriscoowned land formed compact blocks, even if the different plots owned by each individual peasant did not. These blocks were located in the upper section of the irrigation systems of Pasada de Ronda, La Rambla, La Torta, and, finally Almarge (the pago where the watermill 
of Moclón once stood). In Pasada de Ronda the Moriscos had to negotiate the allocation of water with a Castilian known as Corral el Viejo, as their properties bordered his lands. In Almarge, in contrast, there is no evidence of Christian presence, and the whole system, from the catchment area at the Genal River, was owned by Moriscos. La Rambla, which was the sole property of Hernando Retal, and the upper part of La Torta were the other areas where Morisco-owned lands could be found at the time of the expulsion. In La Torta the Moriscos of Moclón had to negotiate the water-distribution slots with the Castilians who owned land downriver. We do not know to what extent the arrival of new colonists may have upset previous water-allocation systems.

The properties that were located nearest to the water-catchment areas were better situated to get an abundant water supply than those situated further down. We do not know what pacts existed, if indeed any existed, to balance out this unequal access to water, or whether the irrigators whose land was further down the system demanded longer or more frequent slots. Such demands were common in this sort of arrangement, especially during times of scarcity, for example during droughts, after the expansion of irrigation areas, and when the crops being grown were particularly water-demanding. Similarly, we are in the dark concerning the crops that Moriscos and Christians grew in their respective fields. This is essential information, for the introduction of new crops, such as maize, and the imposition of new economic criteria which gave preference to cash crops, could have had a very significant impact on demand, and thus have led to tension between the peasants with lands in the upper and lower sections of irrigation systems - a state of affairs that was not at all rare in other cases (Retamero 2016).

As previously noted, the intensively cultivated blocks of land were formed by multiple small properties. The only continuously owned field system was comprised of the seven bancales owned by Hernando Retal in La Rambla. Elsewhere, the Morisco properties were scattered here and there, sometimes even outside the dezmería. We have already mentioned that some lands in Moclón were owned by Moriscos who lived elsewhere. Similarly, some of the Moclón Moriscos had vineyards near Júzcar, to mention but one example (Libro de repartimiento de Júzcar, 1572, fols. 37r and 45r). Further exploration is needed in order to fully understand this crucial issue, which has been abundantly attested in many different social contexts (Berque 1955, pp. 225-227; Bentley 1987; Gallant 1991, pp. 41-45; Netting 1993, p. 39).

The fragmentation of land is often explained as a result of inheritance policies and population growth, the sale of properties, or a change from collective to individual land management (Bentley 1987). It is significant, however, that in Moclón Moriscos favoured intensive practices in small scattered fields which formed compact blocks until the very end: for example, the area of dryland agriculture near the houses and the irrigation areas at the upper end of the irrigation systems. These results, which could not have been reached without fieldwork, suggest that the fragmentation and dispersion of Morisco-owned land plots were a form of risk management: i.e. the distribution of each peasant's property was based on different soil types, maturation characteristics and distance (Bentley 1987, pp. 50-54; Marston 2011). This approach persisted despite the appropriation of most of the land by the Castilians after the conquest. It is, therefore, possible that this dispersion was part of a collective resource-management strategy, similar to those implemented for the allocation of 
water, the maintenance of irrigation systems and the use of pastures (Maass and Anderson 1986; Ostrom 1990). This collective design limited the individual's ability to develop large and compact properties, which are generally associated with the adoption of specialized agricultural strategies. The example posed by the seven tiny continuous plots owned by Retal illustrates sufficiently these limitations.

More examples of the coexistence of Morisco- and Castilian-owned lands are needed in order to ascertain whether the segregation and fragmentation of the former was the result of the plundering and occupation of the vegas and largest dry fields by the new colonists, or a result of the stubborn survival of former subsistence strategies. Naturally, these are not mutually exclusive possibilities. Equally, we still have to elucidate if the fragmentation of Morisco fields is the result of fragmentation by sale or inheritance of formerly compact properties, or if, on the contrary, it was a way of preserving the indigenous social order which was definitively destroyed with the expulsion in 1570 .

\section{Acknowlegments}

This research is being supported by the Spanish Government's Plan Nacional de I-D-i, Producciones y espacios agrarios en sociedades ibéricas de la baja edad media. Estudios desde la arqueología histórica (siglos XII-XVI) HAR2013-42195-P. Ignacio Díaz kindly read the draft and made valuable comments. The authors, however, are the only responsible for the errors and interpretations.

\section{References cited}

Acién, M. (1979). Ronda y su Serranía en tiempo de los Reyes Católicos. Universidad de Málaga, Málaga.

Barceló, M., Kirchner, H. and Navarro, C. (1996). El agua que no duerme. Editorial El Legado Andalusí, Granada.

Barrios, M. (1993). Moriscos y repoblación: en las postrimerías de la Granada islámica. Diputación Provincial de Granada, Granada.

Barrios, M. (2008). La convivencia negada. Historia de los moriscos del Reino de Granada. Editorial Comares, Granada.

Bartlett, R. (1993). The making of Europe. Conquest, colonization and cultural change, 9501350. Princeton University Press, Princeton. 
Baschet, J. (2009). La civilización feudal: Europa del año mil a la colonización de América. Fondo de Cultura Económica, México D. F.

Baydal, V. and Esquilache, F. (2014). Exploitation and differentiation: economic and social stratification in the rural Muslim communities of the Kingdom of Valencia, 13th-16th centuries. In Beyond lords and peasants: rural elites and economic differentiation in premodern Europe, Publicacions de la Universitat de Valencia, Valencia, pp. 37-67.

Becerra, M. and Siles, F. (2013). El libro de repartimiento de Moclón: historia, paisaje rural y poblamiento de una pequeña alquería de El Havaral (siglos XV y XVI). Editorial La Serranía, Ronda.

Bentley, J. W. (1987). Economic and ecological approaches to land fragmentation: In defense of a much-maligned phenomenon. Annual Review of Anthropology, 16: 31-67.

Berque, J. (1955). Structures sociales du Haut Atlas. Presses Universitaires, París.

Catlos, B. A. (2004). The victors and the vanquished: Christians and Muslims of Catalonia and Aragon, 1050-1300. Cambridge University Press, Cambridge.

Colás, G. (1993). Cristianos y Moriscos en Aragón: una nueva lectura de sus relaciones y comportamientos en el marco de la sociedad rural. Mélanges de la Casa de Velázquez, 29(2): $153-170$.

Domínguez A. and Vincent, B. (1978). Historia de los moriscos: vida y tragedia de una minoría. Revista de Occidente, Madrid.

Esquilache, F. (2009). Sobre la rigidez de los sistemas hidráulicos y la evolución del parcelario en las huertas de moriscos. El caso de la acequia de Alèdua. In Actas del XI Simposio Internacional de Mudejarismo, Instituto de Estudios Turolenses, Teruel, pp. 379392.

Ferrer, A. (2015). Captius i senyors de captius a Eivissa. Una contribució al debat sobre l'esclavitud medieval (segles XIII-XVI). Publicacions de la Universitat de València, València.

Ferrer, M. T. (2002). Las comunidades mudéjares de la Corona de Aragón en el siglo XV: la población. In De mudéjares a moriscos : una conversión forzada : actas, Centro de Estudios Mudéjares, Teruel, pp. 27-154.

Furió, A., and García-Oliver, F. (1985-86). Dificultats agràries en la formació i consolidació del feudalisme al País Valencià. Estudi General 5: 291-310.

Galán, A. (1987). Poder cristiano y colaboracionismo mudéjar en el reino de Granada (14851501). In López de Coca Castañer, J. E. (ed.), Estudios sobre Málaga y el Reino de Granada en el V Centenario de la Conquista, Universidad de Málaga, Málaga, pp. 271-289.

Galán, A. (1991). Los mudéjares del reino de Granada. Universidad de Granada, Granada.

Galán, A. (2000). Segregación, coexistencia y convivencia: los musulmanes de la ciudad de Granada. In González Alcantud, J. A., and Barrios Aguilera, M. (eds.), Las tomas: 
antropología histórica de la ocupación territorial del Reino de Granada, Universidad de Granada, Granada, pp. 319-379.

Galán, A. (2007). La política con los mudéjares: de la segregación a la integración. In Ribot, L., Valdeón, J., and Maza, E. (coords.), Isabel la Católica y su época. Actas del congreso internacional 2004, Instituto Universitario de Historia Simancas, Valladolid, pp. 1021-1046.

Galán, A. (2010). Una sociedad en transición: los granadinos de mudéjares a moriscos. Universidad de Granada, Granada

Galán, A., and Peinado, R. G. (1997). Hacienda regia y población en el reino de Granada. La geografía morisca a comienzos del siglo XVI. Universidad de Granada, Granada.

Gallant, Th. W. (1991). Risk and Survival in Ancient Greece. Stanford University Press, Stanford.

Gerrard, C. (1999). Opposing identity: muslims, christians and the military orders in rural Aragon: muslims, christians and the military orders in rural Aragon. Medieval archaeology: Journal of the Society for Medieval Archaeology, 43: 143-160.

Glick, T. F. (1989). Las técnicas hidráulicas antes y después de la conquista. In En torno al 750 aniversario: antecedentes y consecuencias de la conquista de Valencia, Generalitat Valenciana, Valencia, pp. 53-72.

Glick, T. F. (1996). Irrigation and Hydraulic Technology. Medieval Spain and its Legacy. Variorum, Norfolk.

González, M. (1988). Los mudéjares andaluces (ss. XIII-XV). In Andalucía entre oriente y occidente, (1236-1492): actas del V Coloquio Internacional de Historia Medieval de Andalucía, Diputación de Córdoba, Córdoba, pp. 537-550.

Guichard, P. (1992). Les mudéjars de Valence au XIIIe-XIVe siècles. Revue du Monde Musulman et de la Méditerranée, 64: 195-200.

Guinot, E. (2008). Agrosistemas del mundo andalusí: criterios de construcción de los paisajes irrigados. In Cristiandad e Islam en la Edad Media hispana: XVIII Semana de Estudios Medievales, Nájera, del 30 de julio al 3 de agosto de 2007, Instituto de Estudios Riojanos, Logroño, pp. 209-238.

Jané, A. (1985-86). La conquista de Manûrqa al febrer de 1287. Estudi General, 5-6: 389401.

Jones, G. (2005). Garden cultivation of staple crops and its implications for settlement location and continuity. World Archaeology, 37: 164-176.

Kirchner, H. (2009). Original design, tribal management and modifications in medieval hydraulic systems in the Balearic Islands (Spain). World Archaeology, 41(1): 151 - 168.

Kirchner, H., and Navarro, C. (1994). Objetivos, métodos y práctica de la arqueología hidráulica. Arqueología y territorio medieval, 1: 159-182. 
Ladero, M. A. (1969). Granada: Historia de un país islámico (1232-1571). Editorial Gredos, Madrid.

Ladero, M. A. (1981). Los mudéjares de Castilla en la Baja Edad Media. In Actas del I Simposio internacional de mudejarismo, Instituto de Estudios Turolenses, Teruel, pp. 349390.

Ladero, M. A. (1988). Granada después de la conquista: repobladores y mudéjares. Diputación Provincial de Granada, Granada.

Ladero, M. A. (1993). Castilla y la conquista del reino de Granada. Diputación Provincial de Granada, Granada.

Laliena, C. (2005). Frontera y conquista feudal en el valle del Ebro desde una perspectiva local (Taute, Zaragoza, 1086-1200). Studia Historica. Historia Medieval, 23: 115-138.

Laliena, C. (2008). Hidráulica mudéjar en una sociedad feudal. Infraestructura, producción y renta en el regadío musulmán del Valle del Ebro en los siglos XII y XIII. In IX Simposio Internacional de Mudejarismo, Instituto de Estudios Turolenses, Zaragoza, pp. 279-303.

Libro de repartimiento de Júzcar (1572). Archivo Histórico Provincial de Granada, Libros de Población, libro 6730.

López, E. (2013). Aplicación de la «arqueología hidráulica» al estudio de las comunidades campesinas tardo-andalusies: el caso de Tolox (Málaga). Universidad de Granada, Granada.

López de Coca, J. E. (1994). La conversión general en el obispado de Málaga (1500-1501). Chronica Nova 21: 191-237.

Maass, A., and Anderson, R. L. (1986).... and the Desert shall rejoice. Conflict, growth, and justice in arid environments. Robert E. Krieder Publishing Company Inc., Malabar, Florida.

Malpica, A. (1995). Arqueología de los paisajes medievales granadinos: medio físico y territorio de la costa de Granada. Arqueología y Territorio Medieval, 2: 25-62.

Malpica, A. (1997). El paisaje agrario medieval en el reino de Granada. Fuentes escritas y análisis arqueológico. In González Alcantud, J. A., González de Molina, A., González de Molina, M., Malpica Cuello, A., and Vignet-Zunz, J., (eds.), Transformaciones agrarias y cultura material en Andalucía Oriental y Norte de Marruecos, Ministerio de Agricultura, Pesca y Alimentación, Madrid, pp. 15-61.

Malpica, A. (1999). El paisaje del mundo rural andalusí. Bases descriptivas para su análisis. P. H. Boletín del Instituto Andaluz del Patrimonio Histórico, 27: 140-147.

Malpica, A. (2006). El paisaje rural medieval en la Vega de Granada y la ciudad de Ilbira. Arqueología espacial, 26: 227-242. 
Malpica, A. (2014). Las últimas tierras de al-Andalus. Paisaje y poblamiento del reino nazari de Granada. Consorcio para la Conmemoración de la Fundación del Primer Milenio del Reino de Granada, Granada.

Martínez-Enamorado, V. (2006). Torrox. Un sistema de alquerías andalusíes en el siglo XV según su Libro de Repartimiento. Editorial Ajbar, Málaga.

Martínez-Enamorado, V., and Castillo, J. A. (eds.). (2007). El fin de al-Ándalus en la Serranía de Ronda: la rota del Calaluz. Editorial La Serranía, Ronda.

Marston, J. M. (2011). Archaeological markers of agricultural risk management. Journal of Anthropological Archaeology, 30 (2): 190-205.

Mas, A. (2005). Esclaus i catalans. Esclavitud i segregació a Mallorca durant els segles XIV $i X V$. Lleonard Muntaner ed., Palma de Mallorca.

Netting, R. M. (1993). Smallholders, Householders: Farm Families and the Ecology of Intensive, Sustainable Agriculture. Stanford University Press, Stanford.

Ortega, P. (2000). Musulmanes en Cataluña. Las comunidades musulmanas de las encomiendas templarias y hospitalarias de Ascó y Miravet (siglos XII-XIV). CSIC, Barcelona.

Ostrom, E. (1990). Governing the Commons: The evolution of institutions for collective action. Cambridge University Press, Cambridge.

Peinado, R. G. (2012). El reino de Granada tras la conquista castellana. In Juaristi, J. (ed.), En los umbrales de España: la incorporación del Reino de Navarra a la monarquía hispánica, Gobierno de Navarra, Pamplona, pp. 57-94.

Relación del encabezamiento del alcabala de Moclón (1561). Archivo General de Simancas, Expedientes de Hacienda, legajo 152.

Retamero, F. (2014). ¿'Como solía en tiempos de moros'? Los riegos después de las conquistas. El caso de Casarabonela, Málaga (siglos XV-XVI). In Sanchis-Ibor, C., PalauSalvador, G., Mangue Alférez, I., and Martínez-Sanmartín, L. P. (eds.), Irrigation, Society, Landscape. Tribute to Thomas F. Glick, Universitat Politècnica de València, València, pp. 116-131.

Retamero, F. (2016). Arriba y abajo. Cristianos viejos y españoles en sistemas de irrigación de la provincia de Málaga (España) y de algunos valles de Perú (s. XV-XVII): Un ensayo de comparación. Conference paper presented in Old and New Worlds: The Global Challenges of Rural History; Lisbon, 27-30 January 2016, [https://lisbon2016rh.wordpress.com/programme/papers/] (last visit 8/10/2016).

Rodríguez, E. (2005). Igualeja después de la expulsión de los moriscos (1572-1742). Editorial La Serranía, Ronda.

Sierra de Cózar, P., and Sierra Velasco, J. E. (2013). La Real Fábrica de hoja de lata de San Miguel de Júzcar. Editorial La Serranía, Ronda. 
Soto, R. (1994). La situació dels andalusins (Musulmans i Batejats) a Mallorca després de la Conquesta Catalana de 1230. Mélanges de la Casa de Velázquez, 30: 167-206.

Trillo, C. (1994). La Alpujarra antes y después de la conquista castellana. Universidad de Granada, Granada.

Trillo, C. (2004). Agua, tierra y hombres en Al-Andalus: la dimensión agrícola del mundo nazarí. Editorial Ajbar, Granada.

Trillo, C. (2005). A social analysis of irrigation in Al-Andalus: Nazari Granada (13th-15th centuries). Journal of Medieval History, 31(2): 163-183.

Trillo, C. (2006). La alquería y su territorio en al-Andalus: estrategias sociales de organización y conservación. Arqueología Espacial, 26: 243-262.

Torró, J. (1995). El urbanismo mudéjar como forma de resistencia. Alquerías y morerías en el Reino de Valencia (siglos XIII-XVI). VI Simposio Internacional de Mudejarismo, Instituto de Estudios Turolenses, Zaragoza, pp. 535-585.

Torró, J. (1999). El naixement d'una colònia. Dominació i resistència a la frontera valenciana (1238-1276). Publicacions de la Universitat de València, València.

Torró, J. (2000). Jérusalem ou Valence. La première colonie d'Occident. Annales. Histoire, Sociétées, Civilisations, 55 (5): 983-1008.

Torró, J. (2009a). Vivir como cristianos y pagar como moros. Genealogía medieval de la servidumbre morisca en el reino de Valencia. Revista de Historia Moderna 27: 11-40.

Torró, J. (2009b). Formas de poblamiento y urbanismo. Cómo se organizaron los lugares de habitación de los musulmanes del reino de Valencia (siglos XIII-XVI). In Entre tierra y fe. Los musulmanes en el reino cristiano de Valencia (1238-1609), Publicacions de la Universitat de València, València, pp. 201-217.

Van der Veen, M. (2005). Gardens and Fields: The Intensity and Scale of Food Production. World Archaeology, 37(2): 157-163.

Viciano Navarro, P. (2012). Els peus que calciguen la terra: Els llauradors del País Valencià a la fi de l'edat mitjana. Publicacions de la Universitat de València, Valencia.

Vincent, B. (2000). La organización del territorio y la población. In Barrios Aguilera, M. (coord.), Historia del reino de Granada: vol. 2, La época morisca y la repoblación (15021630), Universidad de Granada, Granada, pp. 35-58.

Vincent, B. (2015). El río morisco. Publicacions de la Universitat de València, València.

Virgili Colet, A. (2001). Conqueridors i colons a la frontera: Tortosa, 1148-1212. Recerques: Història, economia i cultura, 43: 47-76. 
Visita de inspección a Moclón (1571). Archivo General de Simancas, Cámara de Castilla, legajo 2158, documento 66 .

\section{Captions}

Figure 1. Location of Moclón (Málaga. Southern Spain)

Figure 2. District of Moclón

Figure 3. Distribution of the dry fields of Moclón

Figure 4. Distribution of the irrigated fields of Moclón

Photo 1. View of the Havaral district (Genal Valley. Málaga)

Photo 2. View of some irrigated pagos of Moclón 